\title{
JARINGAN SOSIAL DALAM PEMBENTUKAN PERILAKU SISWA
} MEROKOK

\author{
Nawaar Faizatun Ashri \\ Jurusan Pendidikan Sosiologi Antropologi, FKIP, Universitas Sebelas Maret \\ nawaarfa@gmail.com \\ Nurhadi \\ Jurusan Pendidikan Sosiologi Antropologi, FKIP, Universitas Sebelas Maret \\ nurhadi@staff.uns.ac.id

\section{Okta Hadi Nurcahyono} \\ Jurusan Pendidikan Sosiologi Antropologi, FKIP, Universitas Sebelas Maret \\ okta.hadi@staff.uns.ac.id
}

\begin{abstract}
The purpose of this research was to know the social networks of smoking behavior of active smoker students, especially in high school of Surakarta. This study aimed to describe agents that contribute to form this behavior through social ties based on Marwell theory of Social Networks. The methods that used in this study was descriptive qualitative with ethnography approach. The data was collected through interview using WhatsApp application. The data was analyzed with theory of Social Network from Marwell and compared to related researches. Informants in this study were ten high school students in Surakarta who active in smoking behavior. The results of this study indicated that its habit started from curiosity and imitation of others into an action that receive "support" from people around. It could be concluded that student's decision of smoking was determined by their relationship with the social milieu which was also an active smoker, such as family and peer groups.
\end{abstract}

Keywords: High school students, school ethnography, smoking habit, social milieu, social network

\section{Pendahuluan}

Perilaku merokok remaja masih menjadi perhatian dari segi kesehatan dilihat dari tingginya angka prevalensi perokok. Menurut laporan Infodatin Pusat Data Informasi Kementrian Kesehatan Republik Indonesia, secara nasional Indonesia memiliki prevalensi merokok sebesar $29 \%$ pada tahun 2013. Pada tahun yang sama, jumlah perokok laki-laki dewasa meningkat dari 65,8\% tahun 2010 menjadi 66\%, sedangkan perokok wanita dewasa dari 4,1\% menjadi 6,7\% (Suryantisa 2018). 


\section{Grafik 1. Pravelensi Konsumsi Tembakau Penduduk Umur $\geq 15$ Tahun berdasarkan Jenis Kelamin di Indonesia tahun 2007, 2010, dan 2013}

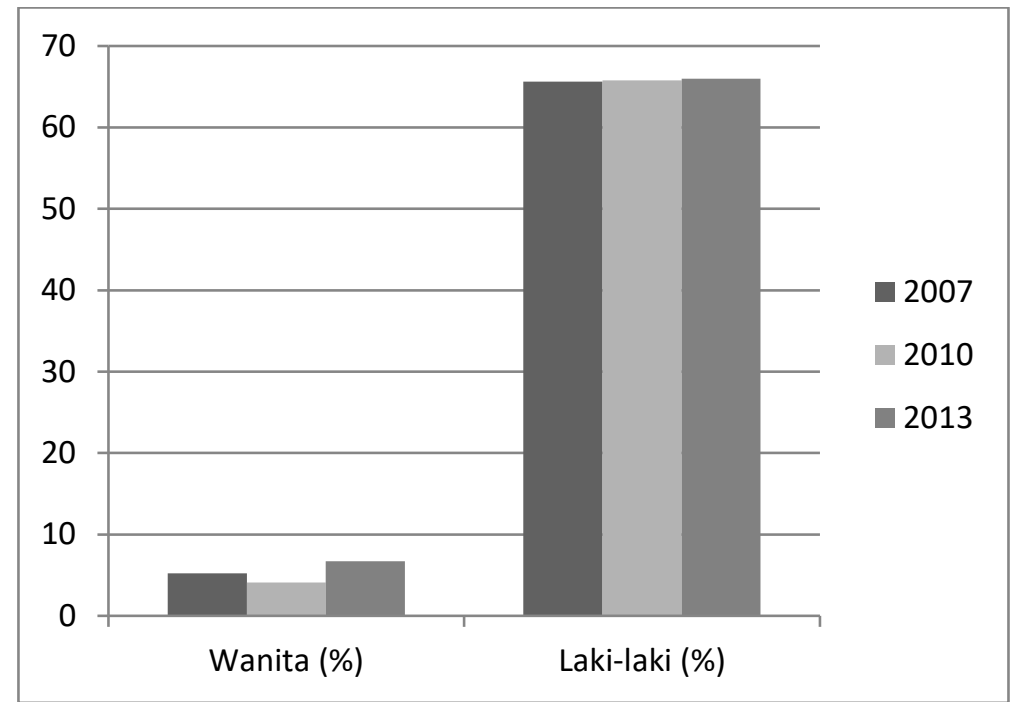

Sumber: RISKESDAS 2007, 2010, 2013

Grafik di atas menunjukkan bahwa perilaku merokok dapat dilakukan siapa saja, baik laki-laki maupun perempuan berusia 15 tahun ke atas. Adanya peningkatan prevalensi merokok dari tahun 2007 ke tahun 2013 juga menunjukkan adanya faktor-faktor tertentu yang mendukung peningkatan ini, khususnya apda remaja.

Dari 33 provinsi yang ada di Indonesia, Provinsi Jawa Tengah menempati peringkat 12 besar pada tahun 2013 dengan prevalensi merokok terbanyak berdasarkan data dari Riskesdas (Kementrian Kesehatan RI \& Badan Penelitian dan Pengembangan Kesehatan, 2013). Provinsi dengan luas wilayah $32.548 \mathrm{~km}^{2}$ serta dihuni oleh 35.557.249 jiwa penduduk ini mengalami peningkatan jumlah perokok berumur $\geq 15$ tahun berdasarkan karakteristik umurnya. Selain itu, perokok terbanyak ditemukan pada penduduk usia 16-19 tahun dengan 41,6\% pada tahun 2010 (Binita, Istiarti, and Widagdo 2016). Dari 35 kota dan kabupaten yang ada di Jawa Tengah, Surakarta merupakan kota dengan jumlah penduduk terbesar ketiga di pulau Jawa. Dalam kaitannya dengan prevalensi merokok, berdasarkan penelitian dari Dinas Kesehatan Kota Surakarta pada tahun 2010 menunjukkan lebih dari 50\% kepala keluarga di Surakarta merupakan perokok (Faridah 2015).

Pemerintah juga sudah menerbitkan beberapa aturan yang diharapkan dapat mengurangi dampak buruk bagi masyarakat, khususnya siswa dari perilaku merokok ini. Merujuk pada pernyataan Tjandra Yoga Adiatama, Kepala Badan Penelitian dan Pengembangan Kesehatan Kementrian Kesehatan dalam keterangan pers yang dirilis CNN Indonesia pada 31 Mei 2015 bahwa dengan mengendalikan kebiasaan merokok anak muda atau pelajar, diharapkan dapat mengurangi jumlah perokok dewasa beserta dampak negatifnya (Wahyuningsih 2015). Merujuk pada hasil survey Global Youth Tobacco Survey (GYTS) Indonesia tahun 2014 menunjukkan bahwa 47,2\% pelajar Indonesia sudah mengalami adiksi terhadap rokok dimana mereka telah sampai pada tahap ingin merokok setiap bangun dan 
hendak tidur (World Health Organization Regional Office for South-East Asia 2015).

Presiden Republik Indonesia telah mengesahkan Peraturan Pemerintah Republik Indonesia No. 109 tahun 2012 pasal 17 tentang pencantuman peringatan kesehatan pada bungkus rokok (Presiden Republik Indonesia 2012). Selain itu, sebagai upaya melindungi generasi muda dari dampak negatif rokok, pemerintah juga mengeluarkan peraturan yang sama, pada pasal 25 yang melarang menjual produk tembakau pada anak di bawah usia 18 tahun.

Dilihat dari data di atas dapat disimpulkan bahwa perilaku merokok remaja merupakan masalah yang cukup serius karena berpengaruh pada kesehatan. Jika tidak adanya tindakan pencegahan kecanduan merokok sejak dini, maka efek negatif yang lebih besar akan dirasakan oleh remaja tersebut. Sebagaimana kesamaan dari hasil penelitian yang relevan mengenai remaja atau siswa merokok beserta faktor yang mempengaruhinya, diketahui pembentukkan perilaku tersebut dapat terjadi karena adanya interaksi dengan individu lain. Oleh sebab itu, penelitian ini akan membahas mengenai jaringan sosial dari interaksi dengan individu lain yang berperan dalam pembentukan perilaku.

\section{Tinjauan Kepustakaan}

Penelitian ini berangkat dari perilaku merokok remaja yang masih berstatus sebagai siswa sekolah. Untuk menjelaskan masalah jaringan sosial dalam pembentukan perilaku merokok ini, perlu dijelaskan mengenai ikatan sosial dan tindakan kolektif yang terangkum dalam teori milik Gerald Marwell. Marwell merupakan salah satu ahli sosiologi dalam mengenai jaringan sosial dalam bukunya berjudul "Social Networks and Collective Action: A Theory of the Critical Mass". Dalam (Marwell and Oliver 1988), jaringan sosial berkaitan dengan tindakan kolektif atau collective action dimana pada suatu kelompok masyarakat didapati adanya ikatan sosial sehingga dalam pengambilan keputusan saling bergantung di antara anggotanya. Kepadatan ikatan sosial menentukan tingginya tindakan kolektif. Ikatan sosial yang dimaksud merupakan ikatan yang terjadi secara langsung. Jaringan sosial menjadi penting ketika ada kepentingan dan keuntungan yang didapatkan oleh pelakunya baik secara materi maupun non materi. Hal inilah yang menjadi landasan mengapa individu berinteraksi dengan individu lain kemudian membentuk jaringan sosial. Bagian-bagian yang perlu dianalisis dalam jaringan sosial menurut Marwell antara lain kepadatan ikatan sosial serta biaya komunikasi antar ikatan.

Dalam artikel ini, konsep yang diterapkan dalam penelitian menggunakan teori Marwell secara sederhana dengan tidak menyertakan penggunaan mesin komputer, sebaliknya, digunakan cara manual untuk menggambarkan bagaimana jaringan sosial perilaku merokok siswa terbentuk menggunakan diagram. Selain secara fisik, individu juga berinteraksi secara non fisik atau virtual di dunia maya. Bentuk interaksi ini juga bisa membentuk suatu jaringan sosial jika interaksi yang berlangsung intens dan terdapat kepentingan yang sama di antara anggotanya. Dengan melihat bentuk interaksi yang terjadi, dapat ditemukan bagaimana informasi dan ide-ide yang membentuk dorongan perilaku siswa merokok.

Penelitian tentang presepsi lingkungan terhadap perilaku merokok menunjukkan bahwa dorongan teman sebaya memberikan banyak kontribusi dalam 
perilaku merokok remaja. Pernyataan ini didukung dengan pemaparan bahwa dorongan teman sebaya dan persepsi lingkungan terhadap perilaku merokok memberikan banyak kontribusi dalam meneruskan perilaku merokok remaja (Sutha 2016). Lebih spesifik, faktor lingkungan yang berhubungan dengan perilaku merokok remaja laki-laki antara lain keluarga yang merokok, teman sebaya yang merokok, serta media masa (Windahsari, Candrawati, and Warsono 2017). Konsumsi siswa terhadap merokok juga dipengaruhi oleh ketersediaan rokok, sikap positif atau negatif terhadap rokok, akses memperoleh rokok serta tingkat paparan iklan rokok (Indra, Edison, and Lestari 2019). Selain itu, pola asuh orang tua terhadap anak ditemukan sebagai salah satu faktor pendorong perilaku ini dengan jenis permisif yang paling dominan di desa Nambuhan, dimana pola asuh ini memberikan kebebasan sebanyak mungkin terhadap anak untuk mengatur dirinya sendiri serta tidak dituntut untuk bertanggung jawab (Permatasari and Wahyuni 2011).

Hubungan signifikan antara jenis kelamin, usia, pengalaman, pengetahuan, dan sikap dengan perilaku merokok remaja. Dalam variabel pegalaman, perilaku merokok didapat dari teman sebayanya yang juga pelaku merokok sehingga membuat individu berlaku sama agar dapat diterima lingkungan pertemanannya. (Wijayanti, Dewi, and Rifqatussa'adah 2017). Kontrol dan pengawasan dari orang tua terhadap anak yang kurang juga dapat berpengaruh pada perilaku merokok anak seperti yang ditemukan pada siswa di salah satu madrasah aliyah di Boyolali (Hasanah 2011). Pengaruh dari kebiasaan merokok yang cukup tinggi ini berpengaruh pada aktivitas belajar siswa yang terganggu (Ria, Imran, and Supriadi 2017). Ketergantungan perokok aktif remaja sebenarnya masih pada tingkat rendah dibandingkan ketergantungan pada lansia sehingga seharusnya lebih mudah dicegah (Risdiana and Wahyu Proboningrum 2019).

Dari uraian tentang penelitian terdahulu yang berkaitan dengan penelitian ini, dapat disimpulkan bahwa hasil yang didapat dari bahasan mengenai lingkungan beserta elemen-elemen di dalamnya merupakan faktor utama dalam pembentukan perilaku merokok. Yang belum dijelaskan dari penelitian-penelitian di atas adalah pembahasan mengenai hubungan atau bagaimana interaksi yang terjadi antara elemen-elemen dari lingkungan tersebut sehingga dapat membentuk suatu perilaku merokok pada remaja. Untuk itu, dalam penelitian artikel ini dibahas mengenai jaringan sosial yang terjadi dalam sebuah lingkungan remaja sehingga menimbulkan perilaku merokok.

\section{Metode Penelitian}

Artikel ini merupakan penelitian kualitatif dengan metode etnografi serta pendekatan kognitif. Informan ditentukan dengan purposive sampling dengan kriteria siswa SMA negeri di Surakarta dan perokok aktif untuk diwawancarai. Selain itu, digunakan juga teknik snowball sampling dengan meminta informan untuk mengenalkan informan lain yang sesuai dengan kriteria yang sudah ditentukan. Setelah itu, informan yang diambil berjumlah sepuluh orang. Wawancara dilakukan secara langsung dengan kelima informan yang sebagian besar melalui percakapan online melalui aplikasi WhatsApp. Setelah wawancara 
selesai, dilakukan pemilihan data yang sesuai dengan pertanyaan penelitian yaitu mengenai jaringan sosial tiap informan yang berkaitan dengan pembentukan perilaku merokok. Bahasa yang digunakan dalam wawancara adalah bahasa Indonesia dengan disisipkan beebrapa kata dalam bahasa Jawa karena bahasa Jawa adalah bahasa ibu dari informan dan peneliti.

Hal yang selanjutnya dilakukan adalah melakukan interpretasi terhadap data yang relevan dengan penelitian. Kemudian dilakuan analisis data menggunakan teori jaringan sosial yang menyatakan bahwa kepadatan ikatan sosial menentukan tingginya tindakan kolektif yang terjadi dalam jaringan sosial seseorang. hal ini dapat ditentukan dari bagaimana ia berinteraksi dengan individu-individu yang ada di jaringan sosialnya serta informasi apa saja yang didapatkannya dalam hal perilaku merokok (Marwell and Oliver 1988). Data yang dihasilkan adalah data kualitatif berupa interpretasi teks yang didapat dari wawancara mengenai pengaruh yang dimiliki aktor terhadap para informan.

\section{Hasil Penelitian dan Pembahasan}

Berdasarkan hasil penelitian yang telah dilakukan, didapatkan data yang diperoleh dari siswa mengenai bagaimana jaringan sosial dalam pembentukan perilaku merokok mereka terbentuk dan bagaimana mereka berinteraksi dengan individuindividu di dalamnya. Lingkungan turut mempengaruhi perubahan dan pembentukkan perilaku individu dengan porsi masing-masing. Begitu pula dengan perilaku yang dianggap menyimpang dari norma dan aturan. Pada dasarnya, perilaku tercipta karena ada proses belajar dari perilaku yang dilakukan orang lain. Frekuensi interaksi yang lebih sering dengan individu atau kelompok tertentu akan lebih berperan sebagai aktor dalam pembentukkan perilaku. Begitu pula dengan perilaku merokok pada remaja, dalam hal ini siswa. Hal ini disebut dengan kepadatan ikatan sosial yang dapat terwujud dengan meningkatkan frekuensi dan kualitas bertemu antara siswa dengan individu lain yang berada di lingkungannya.

Lingkungan siswa yang menjadi fokus utama dalam penelitian ini antara lain lingkungan keluarga, lingkungan tempat tinggal, lingkungan sekolah, dan lingkungan bermain. Dalam Marwell, ikatan sosial yang dianggap adalah ikatan yang terhubung secara langsung terlibat dengan informan. Berdasarkan wawancara yang telah dilakukan, ditemukan ikatan sosial yang terjadi antara siswa dengan teman sebayanya yang terbagi lagi menjadi teman sebaya di lingkungan rumah, lingkungan sekolah, serta lingkungan hobi atau komunitas. Para siswa mulai mencoba merokok untuk pertama kali karena adanya ajakan teman sebaya. Teman di sini merupakan aktor yang berperan penting dalam pembentukkan perilaku merokok.

Rasa penasaran yang sudah ada pada diri siswa akibat orang-orang dewasa di lingkungannya yang menunjukkan perilaku merokok, dikembangkan menjadi sebuah tindakan nyata untuk merokok. Hal ini menunjukkan adanya keterikatan sosial antara ia dengan teman sebayanya sehingga ia bisa memberikan respon positif terhadap ajakan temannya untuk merokok. Hal ini sejalan dengan teori jaringan sosial Marwell yang mengatakan bahwa hubungan jaringan selalu memiliki efek positif pada aksi kolektif. Hubungan jaringan sosial yang lebih padat akan lebih berpengaruh atau lebih memberikan efek positif terhadap terbentuknya 
perilaku merokok. Hubungan jaringan sosial dengan teman sebaya dikatakan lebih padat karena ditemukan bahwa orang tua para siswa ini sebenarnya melarang anak mereka untuk merokok pada usia sekolah, sehingga perilaku merokok ini mereka lakukan secara diam-diam.

Ikatan yang dimiliki informan terhadap teman-temannya juga memiliki kepadatan yang berbeda. Hal ini didasarkan pada kualitas kedekatan pertemanan mereka serta intensitas bertemu yang lebih besar. Kepadatan ikatan yang lebih tinggi juga menunjukkan adanya kepentingan yang lebih tinggi pada ikatan sosial itu dibanding ikatan sosial yang lain. Ikatan dalam jaringan sosial bertujuan untuk menciptakan aksi kolektif para individu yang terlibat. Oleh karena itu, individuindividu yang terlibat dalam jaringan sosial ini "terseleksi" berdasarkan kesamaan kepentingan serta "direkrut" melalui ikatan sosial yang sudah ada sebelumnya. Para siswa dapat membuat ikatan sosial dengan teman sebaya melalui ikatan sosial yang sudah terbentuk sebelumnya. Seorang siswa memiliki ikatan sosial dengan komunitas pecinta motor akibat sebelumnya ia memiliki ikatan sosial dengan teman di tempat tinggalnya yang sudah lebih dulu menjadi anggota komunitas motor itu. Temannya tersebut melihat bahwa ia memiliki ketertarikan yang sama dengannya, sehingga menariknya untuk ikut menjadi anggota komunitas pecinta motor seSurakarta. Pada siswa Y, ia telah merokok sebelum menjadi anggota, sedangkan terdapat anggota yang merokok pada komunitas ini dari berbagai usia.

Komunitas ini merupakan perkumpulan yang berawal dari platform WhatsApp dimana anggotanya direkrut melalui informasi dari mulut ke mulut antara pecinta motor se-Surakarta, seperti halnya siswa ini. Komunitas ini tidak sesering itu melakukan perkumpulan secara langsung, melainkan hanya berkumpul saat acara-acara besar seperti acara tahunan. Selain itu, saat ini siswa sudah tidak lagi mengikuti grup WhatsApp komunitas ini sehingga tidak lagi mengikuti kegiatan-kegiatannya. Sebaliknya, siswa ini lebih sering berkumpul dengan temanteman pecinta motor yang terdiri dari teman-teman rumah dan teman lainnya yang juga memiliki relasi dengan anggotanya. Akan tetapi, ikatan sosial ini bukanlah sebuah komunitas yang bernama, hanya perkumpulan teman sebaya yang kebetulan memiliki hobi sama. Dari dua kelompok hobi ini, siswa mendapatkan "teman" untuk merokok, karena berdasarkan pengakuannya, ia hanya merokok ketika bersama teman-temannya. Meskipun begitu, teman rumahnya tidak dipungkiri memiliki peranan yang lebih besar dibandingkan teman pecinta motornya karena merekalah yang mendorong informan Y untuk melakukan aksi merokoknya serta mengenalkannya pada komunitas hobi ini. Dengan kata lain, karena kepadatan ikatan dengan teman rumahnya, ia bisa menerima gagasan serta informasi yang diberikan dari teman-teman rumahnya dengan lebih mudah (baca diagram 1). 
Diagram 1. Jaringan Sosial Perilaku Merokok Informan Y dan S
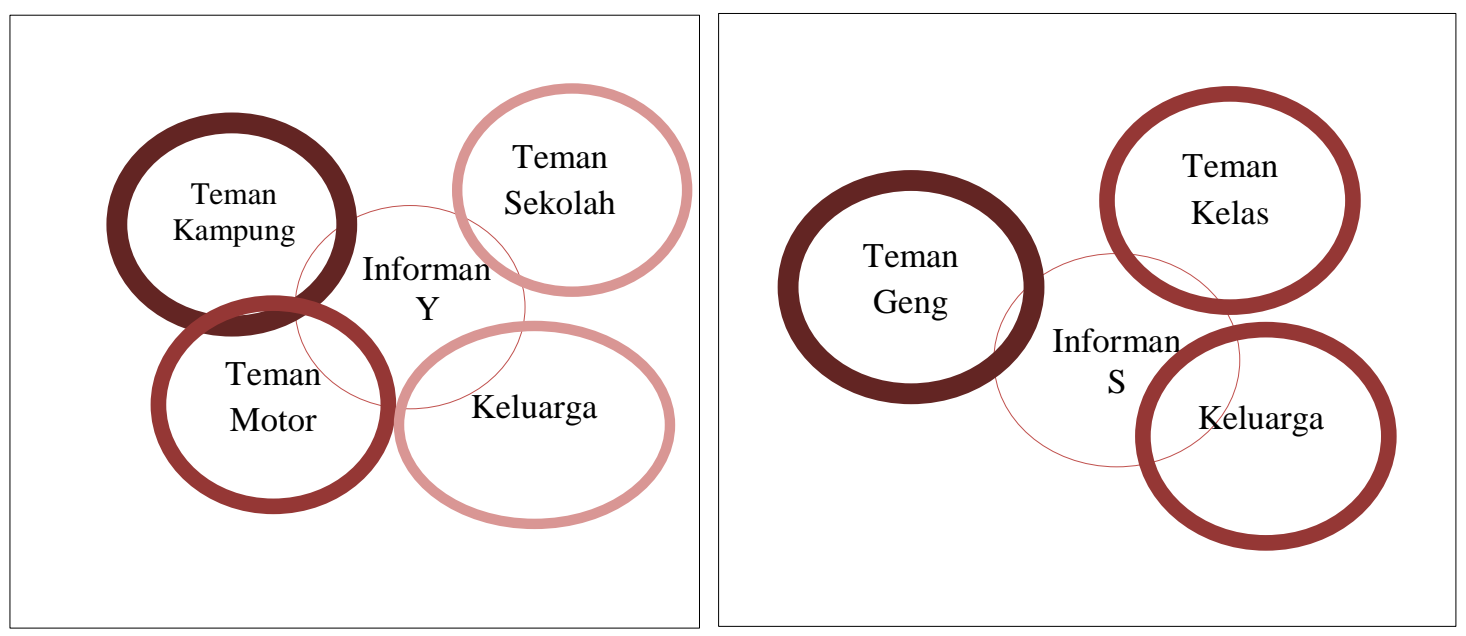

Sumber: data olahan peneliti, 2020.

Pada informan kedua berinisial S yang merupakan siswa kelas sebelas di salah satu SMA negeri di Surakarta, ditemukan bahwa ia pertama kali mencoba merokok saat kelas dua sekolah menengah. Ia mengaku penasaran bagaimana rasa rokok karena kesan yang ia dapatkan dari orang-orang di sekitarnya, seperti keluarga dan teman-temannya yang merokok, adalah terlihat nikmat dan santai. Hal ini yang mendorong munculnya keinginan untuk mencoba merokok. Pada diagram di bawah terlihat bahwa informan memiliki kepadatan ikatan yang lebih tebal dengan teman-temannya dibanding dengan keluarganya yang juga menunjukkan aktor mana yang paling berperan dalam pembentukkan perilaku merokoknya. Berdasarkan wawancara, keluarga terdekat yang memiliki perilaku merokok adalah sang ayah, sedangkan ia dan ayahnya tidak tinggal satu rumah, meskipun tidak jarang juga ia melihat ayahnya merokok. Gambaran perilaku merokok bisa didapatkan informan $\mathrm{S}$ dari sosok ayahnya, meskipun keberanian untuk mencoba merokok itu baru terwujud ketika ia mendapat gambaran merokok dari temanteman sebayanya (baca diagram 1).

Seperti yang digambarkan pada diagram, kepadatan yang paling tebal terlihat pada ikatan sosial Surya dengan kelompok pertemanan dengan teman-teman sekolahnya yang berbeda angkatan yang ia sebut dengan geng. Menurut pernyataan informan, geng ini merupakan kelompok siswa yang memiliki kegemaran sama dalam mendukung atau menjadi supporter pada setiap perlombaan yang diikuti oleh sekolah mereka, khususnya pertandingan olahraga. Adanya kesamaan ini yang menjadi permulaan komunitas nonformal dalam sekolah ini terbentuk. Dari sekian banyak anggotanya, informan ini memiliki kedekatan dengan beberapa orang siswa dari komunitas ini yang kemudian lebih eksklusif disebut geng karena dirasa memiliki kedekatan yang lebih dan frekuensi bertemu di luar sekolah hampir setiap hari. Sehubungan dengan menjadi supporter, terkadang beberapa dari mereka, termasuk informan, melakukan colut atau membolos dari kegiatan belajar mengajar di sekolah kemudian datang ke tempat perlombaan untuk memberi dukungan. Ia mengakui bahwa kebanyakan temannya adalah kakak kelas dua belas dan hampir 
semuanya juga merokok ketika mereka sedang bersama. Selain bertemu pada kegiatan supporter, informan bersama gengnya tadi juga hampir setiap hari bertemu untuk nongkrong di wedhangan pada hari biasa serta di cafe ketika malam minggu dengan dandanan yang lebih rapi daripada saat di wedhangan. Seringnya bertemu dan nongkrong yang selalu dibarengi dengan merokok ini, menjadikan informan memiliki kepadatan ikatan sosial yang lebih tinggi dengan teman gengnya yang berstatus sebagai aktor yang mempengaruhi perilaku merokok informan ini. Walaupun tidak sesering bermain bersama teman satu gengnya, Surya juga kerap kali berkumpul dengan teman sekelasnya yang sama-sama merokok serta memiliki kedekatan dibanding teman sekelasnya yang lain.

\section{Diagram 2. Jaringan Sosial Perilaku Merokok Informan N dan Z}
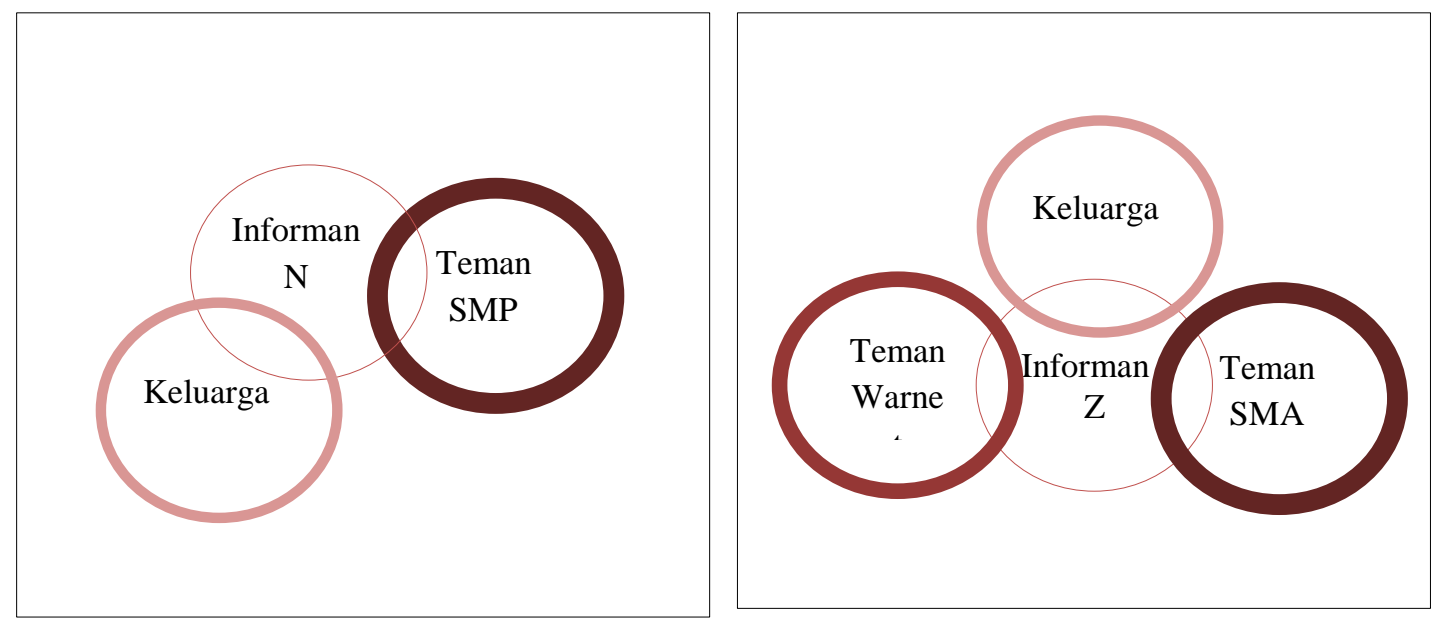

Sumber: data olahan peneliti, 2020.

Pada jaringan sosial informan $\mathrm{Z}$ yang juga merupakan salah satu siswa SMA di Surakarta. Ia mulai merokok sewaktu kelas sepuluh dan memiliki alasan yang mirip dengan informan sebelumnya, yaitu karena teman-temannya merokok. Kemiripan pola informan $\mathrm{Z}$ dengan informan $\mathrm{Y}$ dan $\mathrm{S}$ adalah terdapatnya kelompok hobi yang menjadi salah satu aktor yang berperan dalam pembentukan perilaku merokok ini. Selain merokok bersama teman-teman dari sekolahnya, informan Z juga kerap berkumpul dengan teman-teman yang ia kenal dari warnet serta memiliki keamaan hobi dalam bermain game. Ia mengatakan bahwa ia sering bermain game di warnet sambil merokok bersama mereka. Alasan mengapa kepadatan ikatan sosialnya dengan teman warnetnya lebih tipis dari teman SMAnya adalah karena ia hanya bertemu dengan mereka saat di warnet saja, sedangkan pertemuannya dengan teman SMA-nya terjadi ketika di sekolah dan di luar sekolah, yaitu ketika nongkrong. Nongkrong yang ia lakukan dengan teman-temannya tidak terbatas pada satu tempat saja seperti ketika ia bertemu dengan teman warnetnya. Pertemuannya dengan teman warnetnya juga ia katakan hanya membahas sebatas game saja, berbeda dengan teman sekolahnya yang memiliki lebih banyak topik bahasan serta kepentingan yang lebih luas dan sama. Selain dari lingkungan teman, 
aktor lainnya adalah kakak laki-lakinya yang sudah berusia dewasa dan kerap merokok di rumah. Informan $\mathrm{Z}$ juga beberapa kali diajaknya untuk merokok di luar lingkungan tempat tinggal secara diam-diam karena orang tuanya masih melarang $\mathrm{Z}$ untuk merokok karena belum cukup umur. Pembentukkan perilaku merokok pada informan $\mathrm{Z}$ mendapat dorongan dari lingkungan teman yang memiliki luasnya kepentingan dan ketertarikan yang mereka miliki (baca diagram 2).

Pola jaringan sosial yang mirip juga ditemukan pada jaringan sosial perilaku merokok informan N yang merupakan siswa salah satu SMA di Surakarta. Ia sudah mulai merokok sejak kelas satu sekolah menengah dengan alasan mengikuti temanteman sekolahnya yang sudah lebih dahulu merokok serta memberikan kesan enak menurutnya. Perilaku merokoknya ia lakukan bersama teman-temannya setiap jam istirahat waktu pembelajaran di warung depan sekolah menengahnya yang tentunya diketahui oleh guru mereka, tapi mereka tetap melakukannya walaupun sudah mendapat teguran, bahkan laporan kepada orang tua. Kepadatan ikatan sosialnya dengan teman-teman masa SMP dikatakan paling tebal karena sampai saat ini, informan $\mathrm{N}$ masih terus menjalin komunikasi serta mengadakan pertemuan tiap minggunya meskipun tidak selalu semua teman-teman dapat hadir.

Selain teman SMP sebagai aktor paling berperan dalam pembentukkan perilaku merokok informan $\mathrm{N}$, keluarga serta beberapa teman satu kelasnya di sekolah juga ikut berperan. Ia mengakui bahwa ayahnya sering merokok ketika di rumah, hal ini menjadi gambaran awal baginya mengenai perilaku merokok yang diperlihatkan oleh orang terdekatnya, yaitu keluarganya (baca diagram 2). Di lain sisi, ia mengaku kerap merokok di dalam kamar tidur di rumahnya sehingga ibunya mengetahui perilaku merokoknya. Meskipun begitu, ia tidak mendapatkan peringatan secara langsung dari ayah dan ibunya. Hal ini bisa menjadi salah satu faktor yang menyebabkan ia tetap merokok serta berani merokok di dalam rumah. Kendati sudah merokok cukup lama, ia mengaku menyesal karena perilaku merokok yang terlalu dini membuat kesehatannya terasa menurun meskipun informan $\mathrm{N}$ mengaku sudah kecanduan dan sulit untuk berhenti. Banyaknya perokok di lingkungan sosialnya menjadi salah satu hal yang membuat ia ragu untuk berhenti merokok karena teman sebaya yang memiliki kepadatan sosial tinggi dengannya juga sama-sama memiliki perilaku merokok sejak lama.

Pola yang serupa juga ditemukan pada ikatan sosial yang terbentuk antara informan A dengan lingkungan sosialnya sebagai aktor pembentukkan perilaku merokok. Memiliki ikatan sosial yang padat dengan aktor yang mengajak pertama kali untuk merokok dengan masih menjalin kontak dan pertemuan hingga sekarang. Pada informan A, mulai mencoba merokok pada usia sekolah dasar serta berawal dari memungut rokok bekas di jalan kemudian ia bakar dan bertingkah seolah sedang merokok seperti perilaku orang dewasa yang sering ia lihat. Keberanian untuk merokok sungguhan muncul ketika teman satu sekolah dasarnya yang juga merupakan tetangganya mengajaknya untuk merokok. Aksi merokoknya sewaktu SD masih dilakukan kurang lebih dua bulan sekali karena ia megaku masih takut ketahuan oleh orang tuanya yang kemudian ia sebut sebagai "anak mama". Informan A mengaku sangat dekat dengan dua teman dari SD tersebut hingga kini meskipun salah satu temannya itu sudah putus sekolah saat SMP karena dirasa sudah melalui susah senang bersama sejak kecil. Kepadatan ikatan sosial yang 
terjalin ini mempengaruhi terbentuknya perilaku merokok pada informan A meskipun keluarganya sendiri melarang dirinya untuk merokok serta tidak ada satupun keluarga yang tinggal di rumahnya yang merokok. Dari wawancara, didapatkan bahwa orang tuanya sampai saat ini belum mengetahui mengenai perilaku merokoknya karena ia cukup rapi dalam menyembunyikan dengan cara cuci tangan dan sikat gigi sebelum bertemu dengan orang tuanya serta tidak merokok di sekitar tempat tinggalnya karena rawan ketahuan. Hal ini menunjukkan bahwa informasi dari teman dekatnya lebih diterima ketimbang dari keluarganya sendiri.

\section{Diagram 3. Jaringan Sosial Perilaku Merokok Informan I dan A}

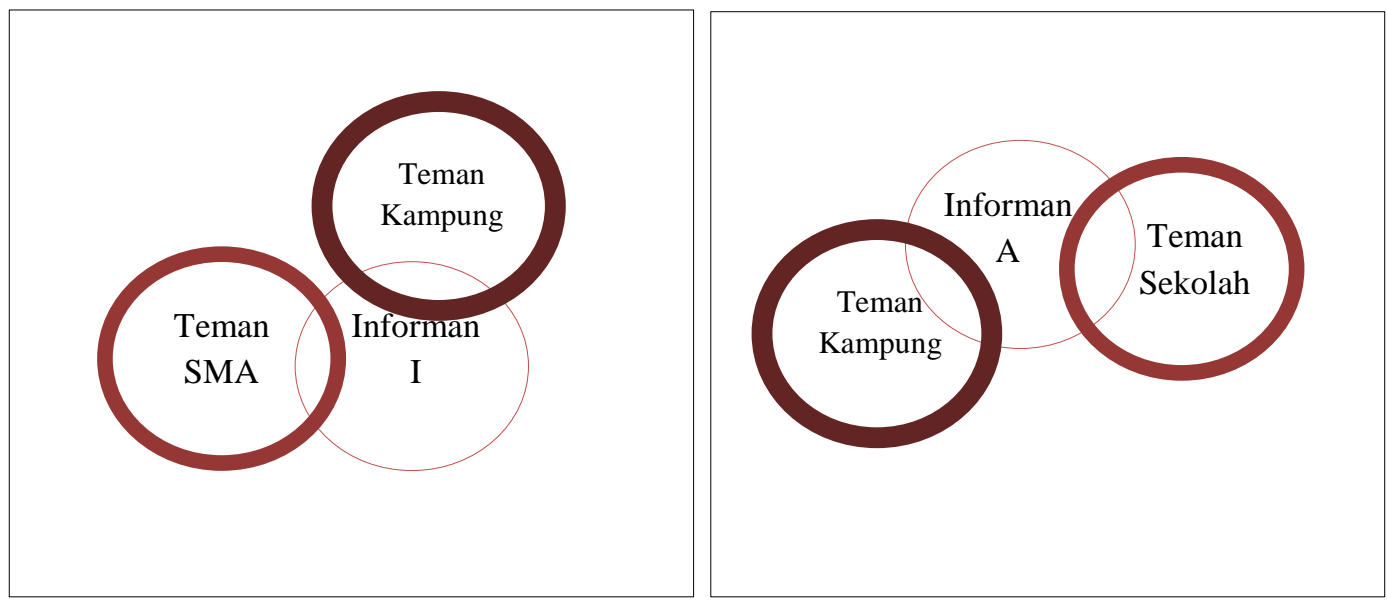

Sumber: data olahan peneliti, 2020.

Pola yang mirip dengan informan A juga ditemukan pada jaringan sosial siswa SMA berinisial I dan O. Dalam ikatan sosialnya ditemukan dua aktor yang berperan dalam pembentukkan perilaku merokoknya adalah teman dari sekolah menengah mereka serta teman dari tempat tinggal mereka yang merokok. Untuk informan I, ia mulai merokok saat sekolah menengah pertama karena teman-teman dekatnya yang merupakan satu sekolah lebih dulu merokok kemudian ia penasaran ingin mencobanya. Teman dari tempat tinggalnya memiliki kepadatan ikatan sosial yang lebih tebal karena ia mengaku lebih dekat dan sering bertemu dengan temanteman rumahnya yang sekaligus merupakan teman sekolah menengahnya. Dari kedua lingkungan pertemanan yang ia miliki ini, keduanya berisi individu yang memiliki perilaku merokok sehingga memudahkan informan I untuk memiliki perilaku yang sama (baca diagram 3). Hal ini mirip dengan aktor pembentukkan perilaku merokok pada informan $O$ yang sama-sama merupakan siswa SMA di Surakarta. Hal yang berbeda adalah informan $\mathrm{O}$ mulai merokok sejak kelas satu SMA dan mengaku hanya merokok ketika sedang bersama teman-teman yang perokok. Dari wawancara, ia mengakui bahwa keinginannya merokok timbul karena kesan yang ia dapatkan dari teman-teman perokoknya adalah kenikmatan serta ia merasa tanggung bila hanya menjadi perokok pasif, kemudian memutuskan untuk ikut merokok (baca diagram 5).

Informan selanjutnya adalah informan F yang merupakan siswa yang berasal dari Jambi lalu bersekolah di Surakarta sejak masuk SMA serta tinggal di kos 
seorang diri. Ketika liburan tiba, ia kembali ke Jambi untuk bertemu keluarganya dan menghabiskan liburannya untuk membantu ayahnya bekerja di peternakan burung lawet milik mereka. Ia mengaku sudah merokok sejak SMP saat masih tinggal di Jambi dengan pengaruh dari teman-temannya yang sudah lebih dahulu merokok kemudian membuatnya ingin mencoba. Ketika kelas sepuluh sekolah menengah atas, ayahnya mengetahui mengenai perilaku merokoknya itu. Oleh karena sang ayah juga merokok, meskipun kini sudah berhenti, informan $\mathrm{F}$ dibiarkan merokok dengan terkadang tetap dinasihati. Menurut wawancara dengan informan $\mathrm{F}$, ayahnya berpendapat sebuah hal yang wajar jika anak laki-laki merokok. Hal ini yang membuatnya tidak canggung jika merokok di depan ayahnya saat berada di peternakan. Meskipun begitu, ibunya sendiri tidak menyetujui perilaku merokok anaknya tersebut yang ditunjukkan dengan kemarahan saat pertama mengetahui anaknya merokok (baca diagram 4).

Diagram 4. Jaringan Sosial Perilaku Merokok Informan F dan D
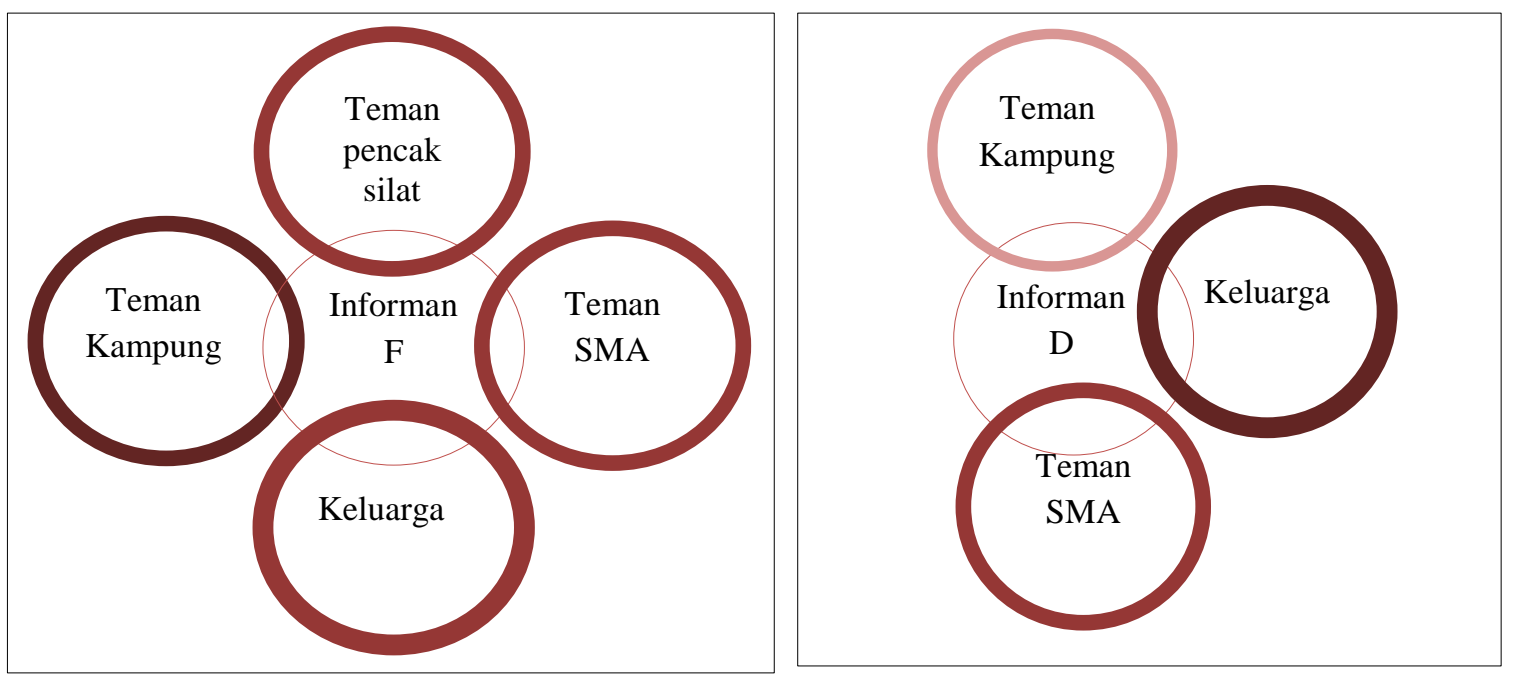

Sumber: data olahan peneliti, 2020.

Setelah pindah ke Surakarta, ia mengikuti kegiatan pencak silat di luar sekolah yang mengadakan pertemuan rutin setiap minggunya. Kegiatan ini diikuti oleh berbagai usia serta menurut pengakuan informan, memiliki ikatan kekeluargaan yang erat. Selain itu, dalam setiap pertemuan, anggotanya cukup terbuka dengan perilaku merokok yang dilakukan siswa sehingga mereka tidak canggung apabila merokok bersama. Informan $\mathrm{F}$ juga mengatakan bahwa mudahnya membeli rokok sekalipun sedang memakai seragam ia rasakan ketika di Jambi maupun di Surakarta.

Diagram selanjutnya menjelaskan tentang ikatan sosial yag dimiliki informan lain dengan inisial D dalam pembentukkan perilaku merokoknya. Siswa kelas XI ini mulai merokok ketika ia masih bersekolah di salah satu SMK di Surakarta sebelum ia pindah ke SMA tempat ia bersekolah kini. Informan D mengatakan meskipun bersekolah di SMK swasta yang cukup favorit dan disiplin, pergaulannya dengan teman-temannya di luar sekolah yang perokok membuatnya penasaran 
hingga ikut menjadi perokok hingga pindah sekolah. Di SMA, ia tergabung dalam club voly sekolah dan sering mengikuti perlombaan. Meskipun menjadi atlet, informan D tidak mendapat larangan atau hambatan dalam merokok sekalipun sang pelatih mengetahuinya karena telah diizinkan. Siswa ini biasa merokok setelah pulang sekolah dan ketika sudah berada di luar lingkungan sekolah. Berbeda dengan informan lainnya yang ditemui, informan D tidak canggung untuk merokok di rumahnya karena keluarganya sudah mengetahui da mengizinkannya untuk merokok selama ia menggunakan penghasilannya sendiri dari COD part motor serta tetap berolahraga. Informan D mengaku merokok semata-mata untuk membuat otaknya rileks dan dapat berfikir jernih mengenai rencana-rencananya ke depan. Kesan ini ia dapatkan setelah berkali-kali merokok serta menjadikannya alasan yang membuat ia terus merokok hingga kini.

Pola kepadatan ikatan sosial yang berbeda dengan informan-informan sebelumnya ditemukan pada dua informan ini yaitu informan F dan D. Lingkaran keluarga dengan garis lebih tebal menunjukkan adanya kepadatan ikatan yang lebih tebal dari lainnya dalam hal pembentukkan perilaku merokok informan (baca diagram 4).

\section{Diagram 5. Jaringan Sosial Perilaku Merokok Informan V dan O}
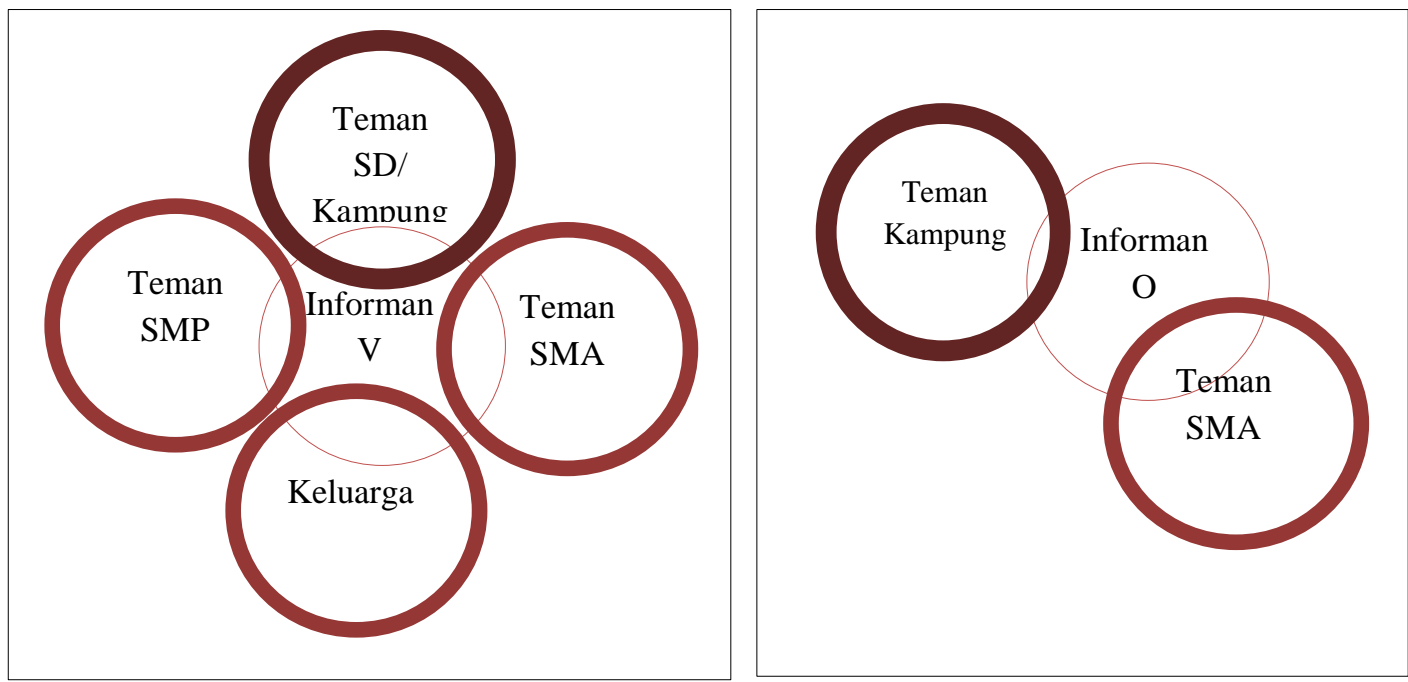

Sumber: data olahan peneliti, 2020.

Perilaku merokok informan $\mathrm{V}$ yang merupakan siswa kelas sebelas didorong oleh aktor yang ada di lingkungan sosialnya, antara lain keluarga, teman tempat tinggal yang sudah berteman dekat sejak sekolah dasar, teman SMP, serta teman yang bersekolah di SMA yang sama dengannya kini. Ia mengawali perilaku merokoknya saat masih duduk di bangku sekolah dasar akibat ajakan teman-teman sekolahnya yang berasal dari lingkungan tempat tinggal yang sama. $\mathrm{V}$ mengaku merasa penasaran tiap kali melihat teman-temannya merokok yang mengatakan bahwa merokok itu enak. Kesan yang ditangkap $\mathrm{V}$ inilah yang membuatnya mengambil keputusan untuk mencoba rokok rasa menthol bersama teman-teman sekolah dasarnya sepulang sekolah di belakang rumah. Mereka memperoleh rokok 
dari membelinya di warung dengan mudahnya sekalipun mereka masih di di bawah umur (baca diagram 5).

Biaya komunikasi yang digunakan untuk menjaga ikatan sosial tetap ada dapat ditekan dengan adanya perkembangan teknologi, khususnya dalam bidang komunikasi. Dengan berbagai aplikasi sosial media, yang paling sering digunakan adalah WhatsApp, siswa dapat berinteraksi dengan individu-individu yang terkait dalam jaringan sosialnya dengan lebih mudah dan murah. Beberapa dari mereka, misalnya informan $\mathrm{S}$, Y, dan $\mathrm{N}$ memiliki WhatsApp group untuk menyebarkan informasi kepada seluruh anggota kelompok sekaligus. Sedangkan informan lainnya mengaku berkomunikasi secara personal menggunakan WhatsApp juga meskipun tanpa bantuan group.

Dari paparan di atas, dapat dilihat bahwa keluarga menjadi salah satu aktor yang berperan dalam pembentukan perilaku merokok tujuh dari sepuluh informan ini. Meskipun begitu, kepadatan ikatannya berbeda-beda yang ditunjukkan oleh kegelapan warna serta ketebalan garis pada lingkaran. Pada informan $\mathrm{Y}$ dan $\mathrm{N}$, keluarga ditunjukkan dengan lingkaran tertipis karena meskipun ayahnya merokok, orang tuanya melarang Y untuk merokok juga. Begitupun dengan informan $\mathrm{Z}$ yang dilarang oleh orang tuanya, namun diizinkan oleh kakaknya. Pada jaringan sosial mereka, keluarga dianggap sebagai tokoh yang perilakunya dapat ditiru (Ramdan, Iswari, and Wijaya 2013).

Sedangkan pada jaringan sosial lainnya, didapati keluarga menjadi aktor yang memiliki kepadatan ikatan cukup tebal terhadap perilaku merokok siswa. Seperti yang ditemukan pada diagram informan S, F, D, dan V. Pada kasus mereka, terdapat anggota keluarga yang kerap menunjukkan perilaku merokoknya di rumah serta cenderung memberi kebebasan anaknya untuk merokok. Hal ini ditunjukkan dengan ketebalan lingkaran yang berwarna cukup gelap dan tebal. Data ini sejalan dengan hasil penelitian terkait yang menyatakan bahwa pengaruh pola asuh orang tua yang mendorong mandiri dan mengendalikan anak, didapati paling banyak ditemukan pada penyebab perilaku siswa merokok (Noor 2019).

Berbanding terbalik dengan data yang didapat pada jaringan sosial perilaku merokok siswa A, I, dan O yang di dalamnya tidak ada peran keluarga. Meskipun keluarga mereka tidak mencontohkan serta melarang untuk merokok, siswa-siswa ini tetap menjadi perokok aktif di luar sepengetahuan keluarga. Hal ini menunjukkan adanya ketidakterkaitan antara peranan orang tua karena perilaku merokok ini juga diawali dengan rasa penasaran karena melihat teman sebaya mereka yang sudah menjadi perokok aktif lebih dahulu (Pangestuputra, Raharjo, and Fitriangga 2018). Aktor yang memiliki kepadatan ikatan sosial paling tebal yang ditemukan pada informan $\mathrm{Y}, \mathrm{S}, \mathrm{F}, \mathrm{N}, \mathrm{Z}, \mathrm{I}, \mathrm{A}, \mathrm{V}$, dan $\mathrm{O}$ adalah teman sebaya yang sudah lebih dahulu merokok. Aktor teman sebaya ini ada yang berasal dari teman kampung, teman satu SMP, teman geng, serta teman satu SMA. Data ini sejalan dengan pernyataan pada hasil penelitian terkait yang menjelaskan bahwa siswa mengimitasi perilaku merokok teman sebayanya yang berawal dari terkesan dengan perilaku mereka, penasaran, diajak, kemudian mencoba secara sukarela dan berakhir dengan ketergantungan rokok. Hal ini disebabkan oleh seberapa baik pergaulan antara siswa dan teman-teman sebayanya yang perokok aktif (Nurnajmi and Awaru 2018). Aksi kolektif ini dapat terbentuk karena adanya rasa ingin 
diterima oleh kelompok pertemanannya serta peran positif atau negatif yang diberikan signifikan dengan perilaku siswa, seperti yang diungkapkan (Sinuhaji, Pangestuti, and Irawan 2018).

Pada pernyataan informan mengenai waktu mereka pertama kali merokok, yaitu ketika duduk di bangku SMA, SMP, atau bahkan SD menunjukkan adanya kemudahan akses memperoleh rokok. Mereka mengaku membeli rokok di warung dan tidak jarang ketika memakai seragam sekolah. Informan juga mengakui bahwa penjual mengetahui bahwa mereka masih duduk di bangku sekolah, tetapi tetap membiarkannya untuk membeli rokok. Ketersediaan akses ini sejalan dengan hasil penelitian terkait yang menyatakan bahwa mudahnya membeli rokok di warung yang juga mudah di akses karena dekat dengan rumah dan sekolah (Cahyo, Wigati, and Shaluhiyah 2012).

Dari penjabaran di atas, dapat dilihat bahwa meskipun penelitian ini dilakukan dengan teknik snowball dalam pemilihan informannya sehingga sebagian besar informan saling mengenal, ditemukan pola-pola yang berbeda dari keseluruhan informan. Aktor pembentuk perilaku merokoknya juga memiliki ketebalan yang berbeda-beda serta polanya tidak secara persis memiliki kesamaan. Ini membuktikan bahwa perilaku merokok dapat terbentuk oleh jaringan sosial yang tercipta dari adanya kepadatan ikatan sosial antara informan dengan aktoraktor di sekitarnya.

\section{Penutup}

Perilaku merokok siswa tidak muncul dengan sendirinya dari dalam diri melainkan terdapat aktor lingkungan yang berperan. Aktor-aktor ini berasal dari lingkungan keluarga serta lingkungan pertemanan sebayanya. Berdasarkan hasil penelitian dan pembahasan yang telah dipaparkan di atas, dapat disimpukan bahwa:

1. Setiap siswa perokok memiliki pola jaringan sosial yang serupa antara satu sama lain. Motivasi mereka untuk merokok juga bukan murni muncul dari dalam diri melainkan mendapat dorongan dari keluarga atau teman sebaya yang juga perokok aktif. Oleh karena itu, terbentuknya perilaku merokok siswa sangat ditentukan oleh dengan siapa saja ia bergaul. Jika jaringan sosialnya relatif berisi perokok aktif, maka ia cenderung akan menjadi perokok aktif juga.

2. Keluarga dapat menjadi aktor yang memiliki kepadatan ikatan sosial paling tebal sebagai aktor membentuk perilaku merokok siswa jika mereka cenderung membebaskan anaknya untuk merokok asalkan bisa bertanggung jawab atas keputusannya.

3. Teman sebaya menjadi aktor pemicu munculnya keputusan siswa untuk memulai merokok. Siswa melihat perilaku teman-temannya terlebih dahulu, mendapat kesan dari mereka, kemudian mulai mencoba merokok.

\section{DAFTAR KEPUSTAKAAN}

Binita, Anisa Maulida, VG. Tinuk Istiarti, and Laksmono Widagdo. 2016. "Hubungan Persepsi Merokok Dengan Tipe Perilaku Merokok Pada Siswa SMK 'X' Di Kota Semarang.” Jurnal Kesehatan Masyarakat (e-Journal) 
4(5):268-76.

Cahyo, Kusyogo, Putri Asmita Wigati, and Zahroh Shaluhiyah. 2012. "Rokok, Pola Pemasaran Dan Perilaku Merokok Siswa SMA / Sederajat Di Kota Semarang." Media Kesehatan Masyarakat Indonesia 11(1):75-84.

Faridah, Fathin. 2015. "Analisis Faktor-Faktor Penyebab Perilaku Merokok Remaja Di SMK ÂXâ Surakarta.” Jurnal Kesehatan Masyarakat (e-Journal) 3(3):887-97.

Hasanah, Arina Uswatun. 2011. "Hubungan Antara Dukungan Orang Tua, Teman Sebaya, Dan Iklan Rokok Dengan Perilaku Merokok Pada Siswa Laki-Laki Madrasah Aliyah Negeri 2 Boyolali.” GASTER 8(1):695-705.

Indra, Syaiful, Edison Edison, and Yuniar Lestari. 2019. "Faktor Penentu Perilaku Merokok Murid Laki-Laki Sekolah Menengah Atas Di Kota Pariaman.” BKM Journal of Community Medicine and Public Health Berita 35(1):11-16. doi: $10.22146 / \mathrm{bkm} .41854$.

Kementrian Kesehatan RI, and Badan Pnelitian dan Pengembangan Kesehatan. 2013. Riset Kesehatan Dasar 2007-2013. Vol. 1.

Marwell, Gerald, and Pamela E. Oliver. 1988. "Social Networks and Collective Action: A Theory of the Critical Mass." The American Journal of Sociology 94(3):502-34.

Noor, rinalia VM. 2019. "Gambaran Pola Asuh Orang Tua Pada Remaja Perokok DItinjau Dari Teori Diana Baumrind.” E-Jurnal Untag Samarinda 7(1):1-9.

Nurnajmi, and A. Octamaya Tenri Awaru. 2018. "Perokok (Studi Siswa Kalangan Ekonomi Rendah Di SMP Negeri 18 Makassar)." Jurnal Sosialisasi Pendidikan Sosiologi 5(1):108-13.

Pangestuputra, Agil W., Widi Raharjo, and Agus Fitriangga. 2018. "Hubungan Orang Tua Perokok Terhadap Kebiasaan Merokok Pada Siswa SMK-SMTI Pontianak." Jurnal Cerebellum 4(N4):1176-85.

Permatasari, Indah, and Wahyuni. 2011. "Hubungan Pola Asuh Keluarga Dan Lingkungan Teman Sebaya Dengan Perilaku Merokok Pada Rmaja Usia 1120 Tahun Di Desa Nambuhan Kecamatan Purwodadi KOta Purwodadi Kabupaten Grobogan." Gaster 8(1):706-21.

Presiden Republik Indonesia. 2012. Peraturan Pemerintah Republik Indonesia No. 109 Tahun 2012 Pasal 17.

Ramdan, Adam Aulia, Rini Iswari, and Atika Wijaya. 2013. "Fenomena Siswa Perokok (Studi Kasus Di SMA Negeri 3 Demak)." Solidarity: Journal of Education, Society and Culture 2(1):36-44.

Ria, Apriani, Imran, and Supriadi. 2017. "Analisis Aktivitas Belajar Siswa Perokok Kelas XI IIS Berkat Bagi Bangsa." Jurnal Pendidikan Sosiologi Dan Humaniora 6(1):1-11.

Risdiana, Nurvita, and Bikassari Wahyu Proboningrum. 2019. "Perbedaan Tingkat 
Ketergantungan Merokok Antara Perokok Remaja Dengan Perokok Lansia." IJNP (Indonesian Journal of Nursing Practices) 3(1):28-34. doi: 10.18196/ijnp.3190.

Sinuhaji, Eka Pertiwi Br, Edriana Pangestuti, and Ari Irawan. 2018. "Pengaruh Lingkungan Keluarga Dan Peer Group Terhadap Perilaku Konsumsi Rokok (Survei Pada Perokok Kategori Remaja Di Kecamatan Lowokwaru Kota Malang)." Jurnal Administrasi Bisnis 65(1):102-10.

Suryantisa, Intan. 2018. Situasi Umum Konsumsi Tembakau Di Indonesia. Jakarta Selatan.

Sutha, Diah Wijayanti. 2016. "Analisis Lingkungan Sosial Terhadap Perilaku Merokok Remaja Di Kecamatan Pangarengan Kabupaten Sampang Madura." Jurnal Manajemen Kesehatan Yayasan RS.Dr. Soetomo 2(1):43-59. doi: 10.29241/jmk.v2i1.50.

Wahyuningsih, Merry. 2015. "18 Persen Pelajar Indonesia Sudah Jadi Pecandu Rokok." CNN Indonesia 1.

Wijayanti, Erlina, Citra Dewi, and Rifqatussa'adah Rifqatussa'adah. 2017. "FaktorFaktor Yang Berhubungan Dengan Perilaku Merokok Pada Remaja Kampung Bojong Rawalele, Jatimakmur, Bekasi." Global Medical \& Health Communication (GMHC) 5(3):194. doi: 10.29313/gmhc.v5i3.2298.

Windahsari, Nur, Erlisa Candrawati, and Warsono. 2017. "Hubungan Faktor Lingkungan Dengan Perilaku Merokok Pada Remaja Laki-Laki Di Desa T Kabupaten Mojokerto.” Nursing News 2(3):595-606.

World Health Organization Regional Office for South-East Asia. 2015. Global Youth Tobacco Survey (GYTS): Indonesia Report 2014. New Delhi. 